\title{
Alleviating the adverse effects of deficit irrigation in Flame seedless grapevine via Paulsen interstock
}

\author{
Mohamed Ahmed Fayek ${ }^{1}$, Ahmed Abdelhady Rashedy ${ }^{2}$, Amr Ebrahim Mohamed Ali ${ }^{3}$
}

Abstract - Using interstock with a potential genetic base is considered more recent and sustainable strategy for mitigating the water deficit. This investigation was carried out on transplant of Flame seedless (Vitis vinifera) grapevine grafted onto two rootstocks namely; Freedom (Vitis champinii $x$ 1613C) and 1103Paulsen (vitis berlandieri $x$ Vitis rupestris) with or without 1103 Paulsen as interstock to determine its performance under deficit irrigation condition (50\% of field capacity). The results indicated that Paulsen as rootstock or as interstock significantly increased the growth vigor of Flame seedless scion as well as the leaf content of total proline, phenols and sugars. Paulsen rootstock has decreased stomatal conductance, leaf transpiration rate and increased diffusion resistance under 50\% deficit irrigation compared with grafting on Freedom rootstock. Moreover, Paulsen as interstock for Flame seedless grafted onto Freedom rootstock significantly increased relative water content accompanied by an increase in thickness of leaf anatomical characters such as midvein, lamina, palisade, xylem and phloem tissue under deficit irrigation compared with grafts without Paulsen interstock. This study suggests that using Paulsen as interstock, can be an adaptation strategy for water stress through controlling in some morphological, chemical physiological and anatomical responses of scion. Index terms: diffusion resistance; leaf anatomical; peroxidase; proline; stomatal conductance.

\section{Aliviando os efeitos adversos da irrigação deficitária na videira Flame sem sementes via enxerto intermediário de Paulsen}

\begin{abstract}
Corresponding author:
ahmed.rasheedy@agr.cu.edu.eg

Received: August 01,2021

Accepted: November 03, 2021

Copyright: All the contents of this journal, except where otherwise noted, is licensed under a Creative Commons Attribution License.

(cc)) EY
\end{abstract}

Resumo - A utilização de um enxerto intermediário com uma base genética potencial é considerada uma estratégia mais recente e sustentável para mitigar o déficit hídrico. Esta investigação foi realizada em transplante de videira Flame sem sementes (Vitis vinifera), enxertada em dois portaenxertos denominados: Freedom (Vitis champinii x 1613C) e 1103Paulsen (vitis berlandieri $\mathrm{x}$ Vitis rupestris) com ou sem 1103Paulsen como enxerto intermediário para determinar seu desempenho sob condição de irrigação deficitária (50\% da capacidade de campo). Os resultados indicaram que a Paulsen como porta-enxerto ou como enxerto intermediário, aumentou significativamente o vigor de crescimento do enxerto Flame sem sementes, bem como o conteúdo foliar total de prolina, fenóis e açúcares. O porta-enxerto Paulsen diminuiu a conduta estomática, taxa de transpiração das folhas, e aumentou a resistência à difusão sob $50 \%$ de irrigação deficitária, em comparação com o enxerto no porta-enxerto da Freedom. Além disso, a Paulsen como enxerto intermediário para Flame sem sementes, enxertada em porta-enxerto Freedom, aumentou significativamente o conteúdo relativo da água, acompanhada por um aumento da espessura de características anatômicas foliares, como a veia, a lamina, a paliçada, e o tecido do xilema e floema sob irrigação deficitária, em comparação com os enxertos sem o enxerto intermediário de Paulsen. Este estudo sugere que usar a Paulsen como enxerto intermediário pode ser uma estratégia de adaptação para o estresse hídrico através do controle em algumas respostas morfológicas, químicas, fisiológicas e anatômicas do enxerto.

Termos para indexação: resistência à difusão; anatômico foliar; peroxidase; prolina; condução estomática.

\footnotetext{
'Professor at the Pomology Department, Faculty of Agriculture, Cairo University, Giza, Egypt. E-mail: mohamed.fayk@agr.cu.edu.eg(ORCID 839 - 0000-0002-1427-6513)

${ }^{2}$ Assistant teacher at the Pomology Department, Faculty of Agriculture, Cairo University, Giza, Egypt. E-mail: amr.ali@agr.cu.edu.eg(ำciD 0000-0002-8472-692X)

${ }^{3}$ Assistant Professor at the Pomology Department, Faculty of Agriculture, Cairo University, Giza, Egypt. E-mail: ahmed.rasheedy@agr.cu.edu.eg (ORCID 0000-0002-0297-1594)
} 


\section{Introduction}

Grapevine (vitis vinifera) is one of the most important crops in the world (ALSTON and SAMBUCCI, 2019). Globally in terms of production, Egypt is ranked fourteenth with a production of 1641075 tons and the amount of exports is about 99001 tons (FAOSTAT, 2018). Flame seedless grapevine cultivar is considered one of the most important export table grape cultivars. But its production is affected by many stresses; it is sensitive to infection with nematodes (EL-NABI et al., 2013; ABOURAYYA et al., 2019) and soil water deficit (REZAEE et al., 2008). In recent years, the climate change forecast suggests that in the coming years, drought will be a more serious problem in the world. Drought stress is one of the foremost causes of viticulture production reduction worldwide under semiarid regions (CHAVES et al., 2007; MEGGIO et al., 2014). Water deficit can restrict plant water uptake, which ultimately results in disturbing plant functioning and declining productivity (KAPOOR et al. 2020). Many studies have shown that irrigated fields ranging from 30 to $50 \%$ of field capacity cause water stress and a significant decrease in viticulture growth (SATISHA et al., 2007; REZAEE et al., 2008; KOUNDOURAS et al., 2008; MEGGIO et al., 2014).

Selection of grapevine rootstock, not only for phylloxera and nematode resistance, but also for several other characteristics are also required, such as grafting compatibility and abiotic stress tolerance (COOKSON et al., 2013; TSEGAY et al., 2014). In this context, grapevine rootstocks exhibit differential degrees of stress tolerance. Freedom rootstock, for example, is resistant to nematode infection (EL-NABI et al., 2013), but it is sensitive to drought stress, whereas 1103Paulsen is more drought tolerant (KOUNDOURAS et al., 2008; FLEXAS et al., 2009; WILLIAMS, 2010; SERRA et al., 2014). Under drought stress, grapevine rootstock controls physiological and biochemical mechanisms which regulate water extraction capacity, stomatal conductance, transpiration rate, osmoregulator accumulation, and enzyme activity of the scion(SATISHA et al., 2007; TOUMI et al., 2007; VERMA et al., 2010; SERRA et al., 2014; TSEGAY et al., 2014; SUCU et al., 2018). Also, anatomical changes in plant leaves are stimulated, allowing plants to tolerante drought conditions by reducing water loss and maintaining photosynthetic rates (CHARTZOULAKIS et al., 2000; PATAKAS et al., 2003; DA SILVA et al., 2003; HAMEED et al., 2012). Plants can modify the properties of their anatomical leaves to adapt to drought stress in many fruit trees such as olive (ENNAJEH et al., 2010) and apple (LOCATELI et al., 2019). Interstock had a positive effect on solving grafting incompatibility (SOSNA and KORTYLEWSKA, 2013; GIRARDI and FILHO, 2006; AGUS and EKA, 2017), stimulating dwarfing (DI VAIO et al., 2009; AN et al., 2017) and increased productivity (GIL-IZQUIERDO et al., 2004). More recently, interstock is able to increase tolerance to biotic stress (ERTI and AGUS, 2018; SHALTIELHARPAZ et al., 2018).

Few studies indicate the potential role of interstock for improving fruit trees tolerance to abiotic stresses. Interstock of SH6 and M26 improved growth and drought tolerance of Fuji cv. apple under 30 and $60 \%$ of filed capacity (LI et al., 2017). Moreover, "Salustiano" orange (Citrus sinensis L.) interstock improved salinity tolerance of Verna lemon (Citrus limon L) trees (ZAPATA et al., 2003). Also, Valencia orange (C. sinensis) interstock improved salt tolerance and flooding tolerance and in some citrus trees (Citrus sinensis L.) ( GIMENO et al., 2009; GIMENO et al., 2012). Many studies indicated that use of interstock with a length of $10 \mathrm{~cm}$ had the best effect on tree performance (SOSNA and KORTYLEWSKA, 2013; DAS and DHAKAR, 2016) and noted that increasing the interstock length, caused reduction of this effect (DI VAIO et al., 2009).

There is a short knowledge on the effect of interstock on drought tolerance of grapevine. Under drought conditions Paulsen rootstock is more suitable than Freedom rootstocks but it is sensitive to nematodes infection. So, the hypothesis of this study is, does Paulsen as drought tolerance interstock to mitigate the adverse effect of deficit water conditions on Flame seedless grapevine?

\section{Materials and methods}

\section{Plant material and growth condition}

The pots experiment was carried out over two consecutive seasons in 2019 and 2020 at the net greenhouse of Pomology Department, Faculty of Agriculture, Cairo University ( $\left.30^{\circ} 01^{\prime} 04^{\prime \prime} \mathrm{N} 31^{\circ} 12^{\prime} 30^{\prime \prime} \mathrm{E}\right)$. The performance of Flame seedless grapevine cultivar grafted onto two rootstocks, Freedom and 1103Paulsen, with and without 1103Paulsen as interstock was evaluated under deficit water irrigation at $50 \%$ of field capacity. In early June, this experiment was performed on four graft combinations, namely; Flame seedless grafted directly onto both Freedom $(\mathrm{Fl} / \mathrm{Fr})$ and Paulsen rootstocks $(\mathrm{Fl} / \mathrm{P})$, or grafted indirectly using 1103Paulsen as interstock $(\mathrm{Fl} / \mathrm{P} / \mathrm{Fr}$ and $\mathrm{Fl} / \mathrm{P} / \mathrm{P})$. The length of the interstock was 10 $\mathrm{cm}$. All plants are grown in $10 \mathrm{~L}$ black plastic pots filled with washed sandy soil. The average height of the scion was $35 \mathrm{~cm}$ and contained 12 mature leaves. Plants were pruned by lateral shoot removal to provide uniform plants with a single main shoot. The electrical conductivity of the tap water was $0.48 \mathrm{ds} / \mathrm{m}$. For three months, tap water was added early second day to adjust water irrigation at $50 \%$ of field capacity, which was computed by using the following equation: [(FW - DW) / DW x 100], where FW was the fresh weight of soil sample and DW was the 
dry weight of soil sample after oven drying at $85^{\circ} \mathrm{C}$ for 3 days (COOMBS et al, 1987). During the experimental period water level were maintained by weighing pots and calculating the volume of water lost every two weeks. Macro and micro elements were added at weekly of 0.25 strength Hoagland for macronutrients and full strength for micronutrients (FOZOUNI et al., 2012). After three months of exposing plants to deficit water treatment, the following parameters were recorded.

\section{Morphological measurements}

Increase in shoot length $(\mathrm{cm})$, leaves number, shoot dry weight $(\mathrm{g})$, and root dry weight (g) were measured. Leaf area $\left(\mathrm{cm}^{2}\right)$ was calculated using the following equation: Leaf area $(\mathrm{LA})=0.465+0.914 * \mathrm{~W} *$ $\mathrm{L}$ where $\mathrm{W}$ is the leaf width $(\mathrm{cm})$ and $\mathrm{L}$ is the leaf length according to (KHAN et al., 2016).

\section{Biochemical analysis}

A sample of one half gram of fresh leaf ( $7^{\text {th }}$ leave from the shoot apex) was used for the following chemical analysis. Free proline ( $\mu$ mole proline/g FW) using the ninhydrin method (BATES et al., 1973), total phenols (mg/g FW) using Folin ciocalteu method (MNG'OMBA et al., 2008), Peroxidase activity (mg/g FW) according to Hammerschmidt et al. (1982) and Ni et al. (2001) and total soluble sugars $(\mathrm{mg} / \mathrm{g} \mathrm{FW})$ were determined by the phenol sulfuric acid method (DUBOIS et al., 1956). All procedures were carried out using a spectrophotometer (model WPA S2100) at wave lengths of 520, 765, 470 and $490 \mathrm{~nm}$, for proline, total phenols, peroxidase activity and total soluble sugar, respectively.

\section{Physiological measurements}

The following physiological measurements were measured at the end of the experiment on the $7^{\text {th }}$ leaf from the shoot apex.

\section{Relative water content (RWC)}

Ten discs of leaves were weighed to obtain fresh weight (FW). Then, the discs were placed in glass jars containing distilled water in the dark for a period of 24 hours to determine their turgid weight (TW). Finally, the discs were placed in an oven at $65^{\circ} \mathrm{C}$ until they reached constant dry weight (DW). Finally, RWC was calculated using the following formula: [(FW-DW $) /($ TW-DW $) \times$ 100] (MEDEIROS et al. 2012).

\section{Leaf gas exchange measurements}

Transpiration rate $\left(\mu \mathrm{g} \mathrm{H}_{2} \mathrm{O} / \mathrm{cm}^{2} . \mathrm{s}\right)$, diffusion resistance $(\mathrm{s} / \mathrm{cm})$ and stomatal conductance $(\mathrm{cm} / \mathrm{s})$ of the $7^{\text {th }}$ mature leaves of plant were determined according to Surendar et al. (2013) by using a portable steady-state porometer (LI-1600M, LI-COR, Nebraska, USA) during the period between 10:00 am and 12:00 pm with an air temperature of $30^{\circ} \mathrm{C}$, humidity of $(29 \%-30.4 \%)$ and photosynthetically active radiation of $1200 \mathrm{mmol} \mathrm{m}^{-2} \mathrm{~s}^{-1}$.

\section{Anatomical studies}

At the end of the experiment, a microscopic examination was performed on the $5^{\text {th }}$ leaf from the shoot apex of the grafts combination, which demonstrated a remarkable response. Specimens $\left(1 \mathrm{~cm}^{2}\right)$ were taken from the centre of leaves and fixed for at least $48 \mathrm{hrs}$ in F.A.A. (10 $\mathrm{ml}$ formalin, $5 \mathrm{ml}$ glacial acetic acid and $85 \mathrm{ml}$ ethyl alcohol 70\%). The selected materials were washed in 50\% ethyl alcohol, dehydrated in a normal butyl alcohol series, embedded in paraffin wax of melting point $56^{\circ} \mathrm{C}$, sectioned to a thickness of 20 microns, double stained with crystal violet-erythrosin, cleared in xylene and mounted in Canada balsam (NASSAR and EL-SAHHAR, 1998). Photomicrographed sections were read to detect histological manifestations of noticeable responses by light compound microscope (LEICA DM750) and a LEICA ICC50 HD using the Leica Application Suite program.

\section{Statistical analysis}

This experiment contains interaction between two grapevine rootstocks and presence and absent of interstock, including 4 treatments, each one divided into three replicates with total 15 plants for each one. This experiment followed a randomized complete block design and means of the treatments were compared by least significant difference (L.S.D.) at a significance level of 0.05 (DUNCAN, 1955).

\section{Results}

\section{Morphological parameters}

The results in table 1 revealed that Flame seedless grafted onto Paulsen rootstock (F1/P) through the first and second season achieved the highest significant value for shoot length $(13.600 \& 26.167 \mathrm{~cm})$, number of leaves $(28.110 \& 27.553)$, leaf area $\left(77.090 \& 57.057 \mathrm{~cm}^{2}\right)$ and root dry weight $(15.183 \& 13.727 \mathrm{~g})$ as compared with grafts on Freedom rootstock. Also, it was clear that Paulsen interstock between Flame seedless scion and Freedom rootstock (FI/P/Fr) increased shoot length $(12.733 \& 25.333 \mathrm{~cm})$, and root dry weight $(14.803 \&$ $13.210 \mathrm{~g}$ ) in both seasons compared to grafts without Paulsen rootstock (FI/Fr). However, using a piece of Paulsen as interstock within the grafts of Flame seedless on Paulsen (FI/P/P) decreased all the tested morphological parameters. 
Table 1. Effect of deficit water irrigation on morphological measurements of Flame seedless grapevine grafted onto Freedom and Paulsen rootstocks with and without Paulsen interstock.

\begin{tabular}{|c|c|c|c|c|c|c|c|}
\hline & \multirow{3}{*}{$\begin{array}{l}\text { Rootstocks } \\
\text { (A) }\end{array}$} & \multicolumn{3}{|c|}{ First season } & \multicolumn{3}{|c|}{ Second season } \\
\hline & & \multicolumn{2}{|c|}{$\begin{array}{c}\text { Paulsen Interstock } \\
\text { (B) }\end{array}$} & \multirow{2}{*}{$\begin{array}{c}\text { Mean } \\
\text { (A) }\end{array}$} & \multicolumn{2}{|c|}{$\begin{array}{c}\text { Paulsen Interstock } \\
\text { (B) }\end{array}$} & \multirow{2}{*}{$\begin{array}{c}\text { Mean } \\
\text { (A) }\end{array}$} \\
\hline & & Without & With & & Without & With & \\
\hline \multirow{3}{*}{$\begin{array}{l}\text { Increase in Shoot } \\
\text { length }(\mathrm{cm})\end{array}$} & Freedom & $10.933 \mathrm{c}$ & $12.733 a b$ & $11.833 \mathrm{~B}$ & $23.917 \mathrm{c}$ & $25.333 \mathrm{ab}$ & $24.625 \mathrm{~A}$ \\
\hline & Paulsen & $13.600 \mathrm{a}$ & $12.653 \mathrm{~b}$ & $13.127 \mathrm{~A}$ & $26.167 \mathrm{a}$ & $24.667 \mathrm{bc}$ & $25.417 \mathrm{~A}$ \\
\hline & Mean (B) & $12.267 \mathrm{~A}$ & $12.693 \mathrm{~A}$ & & $25.042 \mathrm{~A}$ & $25.000 \mathrm{~A}$ & \\
\hline \multirow{3}{*}{$\begin{array}{c}\text { Leaf } \\
\text { number (n) }\end{array}$} & Freedom & $26.330 \mathrm{~b}$ & $27.107 \mathrm{ab}$ & $26.718 \mathrm{~A}$ & $21.170 \mathrm{c}$ & $25.667 \mathrm{~b}$ & $23.418 \mathrm{~A}$ \\
\hline & Paulsen & $28.110 \mathrm{a}$ & $24.997 \mathrm{c}$ & $26.553 \mathrm{~A}$ & $27.553 \mathrm{a}$ & $18.837 \mathrm{~d}$ & $23.195 \mathrm{~A}$ \\
\hline & Mean (B) & $27.220 \mathrm{~A}$ & $26.052 \mathrm{~B}$ & & $24.362 \mathrm{~A}$ & $22.252 \mathrm{~B}$ & \\
\hline \multirow{3}{*}{$\begin{array}{c}\text { Leaf } \\
\text { area }\left(\mathrm{cm}^{2}\right)\end{array}$} & Freedom & $56.143 \mathrm{c}$ & $62.277 \mathrm{~b}$ & $59.210 \mathrm{~B}$ & $45.970 \mathrm{~b}$ & $49.550 \mathrm{~b}$ & $47.760 \mathrm{~B}$ \\
\hline & Paulsen & $77.090 \mathrm{a}$ & $53.783 \mathrm{c}$ & $65.437 \mathrm{~A}$ & $57.057 \mathrm{a}$ & $49.767 \mathrm{~b}$ & $53.412 \mathrm{~A}$ \\
\hline & Mean (B) & $66.617 \mathrm{~A}$ & $58.030 \mathrm{~B}$ & & $51.513 \mathrm{~A}$ & $49.658 \mathrm{~A}$ & \\
\hline \multirow{3}{*}{ Shoot dry weight (g) } & Freedom & $6.640 \mathrm{a}$ & $7.400 \mathrm{a}$ & $7.020 \mathrm{~A}$ & $6.917 \mathrm{a}$ & $7.290 \mathrm{a}$ & $7.103 \mathrm{~A}$ \\
\hline & Paulsen & $7.947 \mathrm{a}$ & $4.380 \mathrm{~b}$ & $6.163 \mathrm{~A}$ & $7.517 \mathrm{a}$ & $6.707 \mathrm{a}$ & $7.112 \mathrm{~A}$ \\
\hline & Mean (B) & $7.293 \mathrm{~A}$ & $5.890 \mathrm{~B}$ & & $7.217 \mathrm{~A}$ & $6.998 \mathrm{~A}$ & \\
\hline \multirow{3}{*}{ Root dry weight (g) } & Freedom & $12.603 \mathrm{~b}$ & $14.803 \mathrm{a}$ & $13.703 \mathrm{~A}$ & $12.107 \mathrm{~b}$ & $13.210 \mathrm{a}$ & $12.658 \mathrm{~B}$ \\
\hline & Paulsen & $15.183 \mathrm{a}$ & $9.797 \mathrm{c}$ & $12.490 \mathrm{~B}$ & $13.727 \mathrm{a}$ & $13.227 \mathrm{a}$ & $13.477 \mathrm{~A}$ \\
\hline & Mean (B) & $13.893 \mathrm{~A}$ & $12.300 \mathrm{~B}$ & & $12.917 \mathrm{~A}$ & $13.218 \mathrm{~A}$ & \\
\hline
\end{tabular}

Mean for each parameter within each season with the same letter were significantly equal at L.S.D. 5\% level.

\section{Biochemical analysis}

According to the results in table 2, Flame seedless grafted onto Paulsen rootstock without interstock (FI/P) significantly increased content of total proline $(1.100 \&$ $2.567 \mu$ mole proline/g FW), phenols $(8.273 \& 10.643$ $\mathrm{mg} / \mathrm{g} \mathrm{FW})$, peroxidase activities $(25.600 \& 13.933 \mathrm{mg} / \mathrm{g}$ FW), and total soluble sugars $(13.857 \& 11.677 \mathrm{mg} / \mathrm{g}$ FW) in two seasons compared to Flame seedless grafted only on Freedom rootstock (FI/P). Furthermore, Paulsen interstock within Flame seedless grafts onto Freedom $(\mathrm{FI} / \mathrm{P} / \mathrm{Fr})$ increased both proline content $(1.100 \& 2.850$ $\mu$ mole proline/g FW) and phenol content ( $7.857 \& 10.353$ ) in addition to total soluble sugar $(13.427 \& 11.250 \mathrm{mg} / \mathrm{g}$ ) but decreased significantly peroxidase activity (12.667 $\& 12.667)$ through first and second seasons compared to Flame seedless grafted onto Freedom without Paulsen interstock.

\section{Physiological parameters}

Data presented in table 3 revealed that general grafting of Flame seedless on Paulsen rootstock (FI/P) significantly decreased its transpiration rate, stomatal conductance and increased diffusion resistance as compared with grafts of Flame seedless on Freedom rootstock $(\mathrm{FI} / \mathrm{Fr})$. Using of Paulsen as interstock between Flame seedless scion and Freedom rootstock (FI/P/Fr) significantly increased the relative water content of leaves, but did not show a significant effect on other parameters. However, Paulsen interstock between Flame seedless scion and Paulsen rootstock $(\mathrm{F} / \mathrm{P} / \mathrm{P})$ revealed some increase in leaf relative water content despite an increase in transpiration rate and stomatal conductance, there is a significant decrease in diffusion resistance. 
Table 2. Effect of deficit water irrigation on chemical content of Flame seedless grapevine grafted onto Freedom and Paulsen rootstocks with and without Paulsen interstock.

\begin{tabular}{|c|c|c|c|c|c|c|c|}
\hline & \multirow{3}{*}{$\begin{array}{l}\text { Rootstocks } \\
\text { (A) }\end{array}$} & \multicolumn{3}{|c|}{ First season } & \multicolumn{3}{|c|}{ Second season } \\
\hline & & Inte & $\begin{array}{l}\text { aulsen } \\
\text { tock (B) }\end{array}$ & Mean & Inte & $\begin{array}{l}\text { ulsen } \\
\text { ck (B) }\end{array}$ & Mean \\
\hline & & Without & With & (A) & Without & With & \\
\hline \multirow{3}{*}{$\begin{array}{l}\text { Total Proline } \\
\text { content } \\
\mu \text { mole/g FW }\end{array}$} & Freedom & $0.800 \mathrm{c}$ & $1.100 \mathrm{~b}$ & $0.950 \mathrm{~B}$ & $1.750 \mathrm{~d}$ & $2.850 \mathrm{a}$ & $2.300 \mathrm{~B}$ \\
\hline & Paulsen & $1.100 \mathrm{~b}$ & $1.400 \mathrm{a}$ & $1.250 \mathrm{~A}$ & $2.567 \mathrm{~b}$ & $2.467 \mathrm{c}$ & $2.517 \mathrm{~A}$ \\
\hline & Mean (B) & $0.967 \mathrm{~B}$ & $1.267 \mathrm{~A}$ & & $2.158 \mathrm{~B}$ & $2.658 \mathrm{~A}$ & \\
\hline \multirow{3}{*}{$\begin{array}{c}\text { Total phenols } \\
\text { content } \\
(\mathrm{mg} / \mathrm{g}) \mathrm{FW}\end{array}$} & Freedom & $7.280 \mathrm{~b}$ & $7.857 \mathrm{a}$ & $7.568 \mathrm{~A}$ & $10.200 \mathrm{~b}$ & $10.353 \mathrm{~b}$ & $10.277 \mathrm{~A}$ \\
\hline & Paulsen & $8.273 \mathrm{a}$ & $7.307 \mathrm{~b}$ & $7.790 \mathrm{~A}$ & $10.643 \mathrm{a}$ & $10.207 \mathrm{~b}$ & $10.425 \mathrm{~A}$ \\
\hline & Mean (B) & $7.777 \mathrm{~A}$ & $7.582 \mathrm{~A}$ & & $10.422 \mathrm{~A}$ & $10.280 \mathrm{~A}$ & \\
\hline \multirow{3}{*}{$\begin{array}{c}\text { Peroxidase activity } \\
(\mathbf{m g} / \mathbf{g}) \mathrm{FW}\end{array}$} & Freedom & $22.467 \mathrm{~b}$ & $12.667 \mathrm{~d}$ & $17.567 \mathrm{~B}$ & $13.200 \mathrm{~b}$ & $12.667 \mathrm{c}$ & $12.933 \mathrm{~A}$ \\
\hline & Paulsen & $25.600 \mathrm{a}$ & $18.500 \mathrm{c}$ & $22.050 \mathrm{~A}$ & $13.933 \mathrm{a}$ & $10.117 \mathrm{~d}$ & $12.025 \mathrm{~B}$ \\
\hline & Mean (B) & $24.033 \mathrm{~A}$ & $15.583 \mathrm{~B}$ & & $13.567 \mathrm{~A}$ & $11.392 \mathrm{~B}$ & \\
\hline \multirow{3}{*}{$\begin{array}{l}\text { Total sugar content } \\
\text { (mg/g) FW }\end{array}$} & Freedom & $11.573 \mathrm{c}$ & $13.427 \mathrm{~b}$ & $12.500 \mathrm{~B}$ & $10.910 \mathrm{c}$ & $11.250 \mathrm{~b}$ & $11.080 \mathrm{~B}$ \\
\hline & Paulsen & $13.857 \mathrm{a}$ & $13.827 \mathrm{a}$ & $13.842 \mathrm{~A}$ & $11.677 \mathrm{a}$ & $11.387 \mathrm{~b}$ & $11.532 \mathrm{~A}$ \\
\hline & Mean (B) & $12.715 \mathrm{~B}$ & $13.627 \mathrm{~A}$ & & $11.293 \mathrm{~A}$ & $11.318 \mathrm{~A}$ & \\
\hline
\end{tabular}

Mean for each parameter within each season with the same letter were significantly equal at L.S.D. 5\% level.

\section{Leaf anatomical characters}

Data presented in table 4 and figures 1 showed that using Paulsen as interstock between Flame seedless scion and Freedom rootstock $(\mathrm{FI} / \mathrm{P} / \mathrm{Fr})$ increased the thickness of both Collenchyma, midvein, lamina, palisade, xylem and phloem tissue $(73.1,803.2,173.3$, $79.8,81.9$ and $90.4 \mu \mathrm{m}$ ) respectively compared to Flame seedless scion grafted onto Freedom rootstock without Paulsen interstock (FI/Fr). However, Paulsen as rootstock recorded an increase in thickness of Collenchyma, midvein, lamina, palisade, spongy, xylem and phloem of leaves of Flame seedless grafted on it $(73.3,618.3,185.7$, $69.1,75.6,80.6$ and $80.1 \mu \mathrm{m})$ respectively compared to Flame seedless grafted onto Freedom without interstock (FI/Fr) which recorded the lowest values.
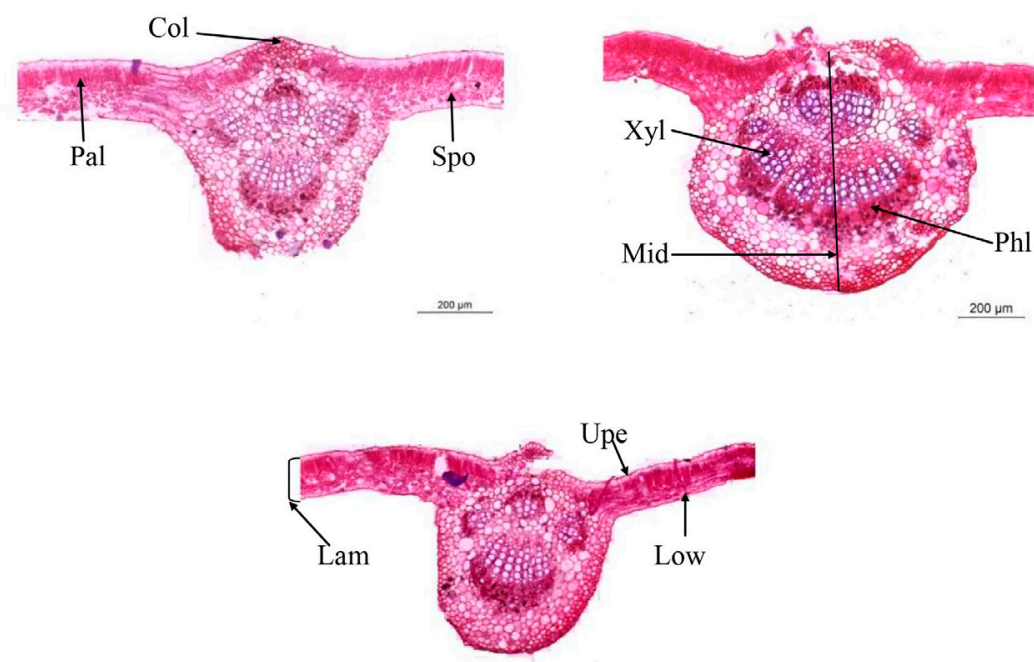

$\underline{200 \mu \mathrm{m}}$

Figure 1. Comparative leaf anatomy in blade cross-sections (100X) Flame seedless grafted onto Freedom (FI/Fr), Flame grafted onto Freedom with interstock (FI/P/Fr), Flame grafted onto Paulsen (Fl/P) under deficit water $(50 \%$ field capacity). Uper ebiderms (Upe), Lower epidermis (Low), Lamina thickness (Lam), Collenchyma thickness (Col), Midvein thickness (Mid), Palisade thickness (Pal), Spongy thickness (Spo), Xylem thickness (Xyl), Phloem thickness (Phl). 


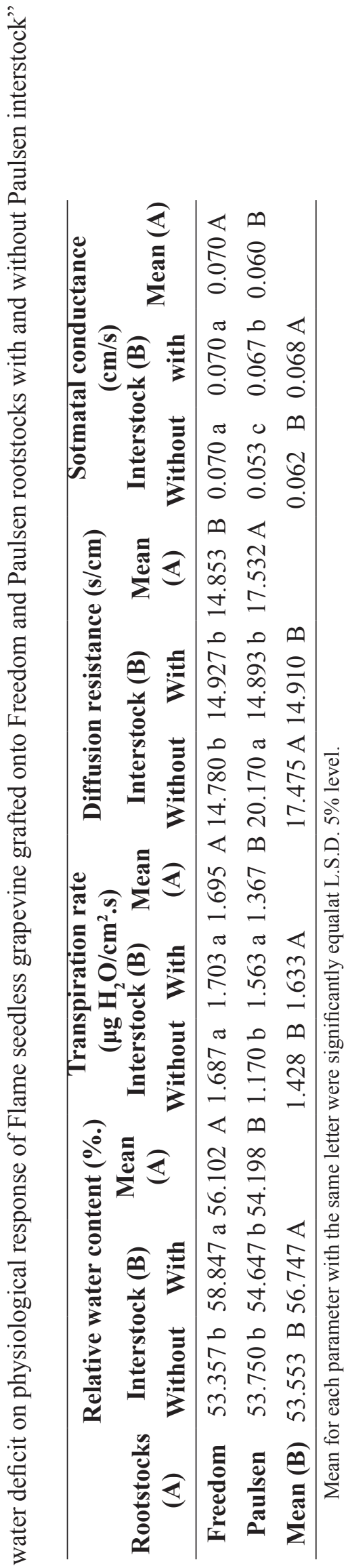

Table 4. Anatomical changes in cross-sections of leaves of grafts compination under deficit water $(50 \%$ field capacity).

\begin{tabular}{cccc}
\hline & $\mathrm{FI} / \mathrm{Fr}$ & $\mathrm{FI} / \mathrm{P} / \mathrm{Fr}$ & $\mathrm{Fl} / \mathrm{P}$ \\
\hline Uper ebiderms thickness & 26.7 & 23.7 & 20.6 \\
Lower epidermis thickness & 21.8 & 20.7 & 20.4 \\
Collenchyma thickness & 70.6 & 73.1 & 73.3 \\
Midvein thickness & 605.7 & 803.2 & 618.3 \\
Lamina thickness & 169. & 173.3 & 185.7 \\
Palisade thickness & 55.2 & 79.8 & 69.1 \\
Spongy thickness & 65.2 & 49.1 & 75.6 \\
Xylem thickness & 59.5 & 81.9 & 80.6 \\
Phloem thickness & 66.2 & 90.4 & 80.1 \\
\hline
\end{tabular}

Flame grafted onto Freedom (FI/Fr), Flame grafted onto Freedom with interstock (FI/P/Fr), Flame grafted onto Paulsen (Fl/P).

\section{Discussion}

It is well known that grapevine rootstocks play a major role in the adaptive response of scions to water limiting conditions (KOUNDOURAS et al., 2008; TRAMONTINI et al., 2013). The present study indicated that Paulsen rootstock improved vigor growth of Flame seedless grapevine under deficit irrigation expressed as shoot length, leaf number and leaf area as well as root dry weight compared with grafts on Freedom rootstock. Previous researches on grapevines reported that deficit water reduce the whole plant growth sharply (LEBON et al., 2006; ARAN et al., 2017; SUCU et al., 2018; MOHSEN et al., 2020). This deficiency may be due to the reduction of cell division, elongation and expansion under water stress (ALVES and SETTER, 2004,; FAROOQ et al., 2012). Moreover, as found in the present study, using Paulsen as interstock within Flame seedless scion onto Freedom rootstock (FI/P/Fr) improved its vigor growth and tolerance to deficit water. These findings agreed with those of Li et al. (2017), who reported that using SH6 and M26 rootstocks as interstock in apple improved the vigor growth of Fuji cv. apple under drought stress. Similarly, El-Tanany et al. (2019) found that using Flying Dragon as an interstock improved the growth and yield of Washington navel orange under deficit irrigation at $75 \%$ of field capacity. Also, The present study sowed that the increase in shoot length in the second season was higher than in the first season. This may be due to the different climatic conditions between the two seasons.

Accumulation of compatible solutes such as proline, phenols, and sugars under water deficit conditions consider the important strategy for avoiding tissue dehydration and maintaining plant water statues (FAROOQ et al., 2012, SANDERS and ARNDT, 2012, KAPOOR et al., 2020). Abdia et al. (2016) recorded a increasing WUE, as well as proline and soluble sugar concentrations in Rasheh grape cultivars as indicator for drought tolerant stress than was Bidane-Sefid cultivar. 
In this context, the results showed that Paulsen rootstock increased significantly in proline content and total sugars of Flame seedless compared to grafts on Freedom rootstock. Furthermore, using Paulsen as interstock increased total proline content, total sugars, and total phenols accumulation while decreasing peroxidase activity of Flame seedless grafted onto Freedom rootstock (FI/P/Fr) compared to grafts without Paulsen interstock (FI/Fr). These results were in agreement with (ELTANANY et al., 2019) as they found that using flying dragon (Poncirus trifoliate) as interstock increased leaf proline content of Washington navel Orange trees under (75\%) deficit irrigation. Proline has a role in increasing the cellular solute content and thus maintaining higher water content of plants (MOHAMMAD et al., 2008' MAFAKHERI et al., 2010). In addition, the results were in line with Jogaiah et al. (2014) as they found accumulation of phenolic compounds under water stress with Paulsen rootstock which has shown tolerance to drought stress. Jogaiah et al. (2014) and Sharma et al. (2019) reported that Phenols may be play as antioxidants for scavenging the reactive oxygen species generated thus maintaining normal physiological and biochemical process of resistant cultivars. Similarly, Toumi et al. (2007) reported that increased total sugar accumulates in some grafts combinations of grapevine is indicator to tolerance of water stress. This may be due to the role of soluble sugar in maintaining the leaf water content, osmotic adjustment (MOHAMMADKHANI and HEIDARI, 2008), membrane protection and scavenging of reactive oxygen species (SAMI et al., 2016). Previous researches on grapevine studied the role of enzyme activity under dehydration stress and they suggested that enzyme activity is an indicator of drought tolerance (ARAN et al., 2017; SUCU et al., 2018). Peroxidase enzyme has a positive role of antioxidants in cellular redox homeostasis during drought stress (MAFAKHERI et al., 2011; ARAN et al., 2017). In our study the highest increase of peroxides activity recorded with Flame seedless grafted onto Paulsen rootstock compared with that grafted onto Freedom rootstock

Drought-tolerant rootstocks in grapevine can improve water extraction from the soil and transfer it to the scion, in addition to controlling stomatal conductance and transpiration rate of scion under water deficit condition (KOUNDOURAS et al., 2008; SERRA et al., 2014; TSEGAY et al., 2014) through chemical signaling such as ABA and compatible solute (SOAR et al., 2006; SERRA et al., 2014; PECCOUX et al., 2017). In the present study, using Paulsen as rootstock decreased stomatal conductance and transpiration of Flame seedless leaves and increased diffusion resistance of stomata. However, Paulsen as interstock with Flame seedless grafted onto Freedom significantly improved relative water content without a significant effect on transpiration rate, diffusion resistance and stomatal conductance. These results were in agreement with Koundouras et al. (2008) as they noted that Paulsen is more water efficient rootstock through decreasing stomatal conductance and transpiration rate of scion grafted on it under water stress.

Many studies have indicated that increase in thickness of leaf anatomical characters such as collenchymas, midvein, lamina, palisade, xylem, phloem and others were related to drought tolerance in plants (CHARTZOULAKIS et al., 1999; NAWAZISH et al., 2006; DE MICCO and ARONNE, 2012; ZULFIQAR et al., 2020). This increase is greater with drought tolerant genotypes compared to sensitive genotypes (EL-AFRY et al., 2012; TOSCANO et al., 2019). This is consistent with our findings, which revealed an increase in the thickness of leaf anatomical characters with graft combinations $(\mathrm{FI} / \mathrm{P} / \mathrm{Fr}$ and $\mathrm{FI} / \mathrm{P})$ that were more tolerant to water stress than graft combinations $(\mathrm{FI} / \mathrm{Fr})$. A thicker palisade tissue may have a role in increasing the number of $\mathrm{CO}^{2}$-fixation sites. A thicker spongy paraenchyma could result in easier diffusion of $\mathrm{Co}^{2}$ to these sites, thus maintaining the photosynthesis rate of leaves under deficit water (ENNAJEH et al., 2010; LOCATELLI et al., 2019). The thickening of the vascular bundles of plant leaves allows for greater flows of water and mineral salts during the water deficit, thus adaptive it to water stress conditions (Queiroz-Voltan et al. 2014). On the other hand, Locatelli et al., (2019) reported that the xylem vessels of leaves were increased in number and were reduced in diameter under deficit water. Thus, it increases resistance to high pressures in the water column. Nawazish et al. (2006) and Taratima et al. (2019) reported that increasing lamina thickness is related to anatomical adaptation under drought. Taratima et al. (2020) indicated that increasing lamina thickness may expand bulliform cells.

\section{Conclusion}

In conclusion, Paulsen as an interstock improved the tolerance of Flame seedless scion to deficit water stress via increasing proline and total sugar content as a biochemical mechanism. In addition, it had positive effects on the physiological response of the scion, such as increasing relative water content and stomatal conductance of the leaf. Furthermore, it caused thickening of midven tissues, lamina, septum, xylem, and phloem in leaves as an anatomical mechanism

\section{Acknowledgment}

The authors thank Cairo University for funding and financial supports. Also, the authors thank Ahlam Ezzat (M.Sc. student)for Technical help. Also, The authors thank Profa. Mônica Maia de Stefani to translate the manuscript title, abstract and keywords into Portuguese. 


\section{References}

ABDI, S.; ABBASPUR, N.; AVESTAN, S; and BARKER, A.V. Sana Physiological responses of two grapevine (Vitis vinifera L.) cultivars to $\mathrm{Cycocel}^{\mathrm{TM}}$ treatment during drought. Journal of Horticultural Science \& Biotechnology, Ashford, v.91, n.3, p.211-219, 2016.

ABOURAYYA, M.S.; NABILA, K.E.; ABD-ALLAH, A.S.E.; AMAL, R.A.M. Effect of grafting date and rootstock type on vegetative growth parameters of Flame seedless grape grafted on three nematode resistant rootstocks. Middle East Journal of Agriculture Research, v.8, n.4, p.967-972, 2019.

AGUS, S; EKA, P.N. Interstock effect on the growth of mandarin cv batu 55, tangerine cv pontianak and lime $\mathrm{cv}$ nimas propagated by grafting. Russian Journal of Agricultural and Socio-Economic Sciences, Orel, v.10, n.70, p.239-246, 2017.

ALSTON, JM.; SAMBUCCI,O. Grapes in the world economy. In: CANTU, D.; WALKER, MA. (ed.). The grape genome. Cham: Springer, 2019. p.1-24.

ALVES, A.A.C; SETTER, T.L. Response of cassava leaf area expansion to water deficit: cell proliferation, cell expansion and delayed development. Annals of Botany, London, v.94, p.605-613, 2004.

AN, H.; LUO, F.; WU, T.; WANG, Y.; XU, X.; ZHANG, $X$.; HAN, Z. Effect of rootstocks or interstems on dry matter allocationin apple. European Journal of Horticultural Science, Stuttgart, v.82, n.5, p. 225-231, 2017.

ARAN, M.; ABEDI, B.; TEHRANIFAR, A; PARSA, M. Physiological and biochemical responses of three Iranian Grapevine cultivars to short-term water deficit stress. Journal of Analytical Sciences, Methods and Instrumentation, Irvine, v.13, n.2, p.355-365, 2017.

BATES, L.S.; WALDREN, R.P.; TEARE, I. Rapid determination of free proline for water-stress studies. Plant and Soil, v.39, n.1, p.205-207. 1973.

CHARTZOULAKIS, K.; BOSABALIDIS, A.; PATAKAS, A.; VEMMOS, S. Effects of water stress on water relations, gas exchange and leaf structure of olive tree. Acta Horticulturaeulturae, v.537, n.2, p.241-247, 2000 .
CHARTZOULAKIS, K.; PATAKAS, A.; BOSABALIDIS, A.M. Changes in water relations, photosynthesis and leaf anatomyinduced by intermittent drought in two olive cultivars. Environmental and Experimental Botany, Amsterdam, v.42, p.113-120, 1999.

CHAVES, M.M.; SANTOS, T.P.; SOUZA, C.R.; ORTUNO, M.F.; RODRIGUES, M.L.; LOPES, C.M.; MAROCO, J.P.; PEREIRA, J.S. Deficit irrigation in grapevine improves water-use efficiency while controlling vigour and production quality. Annals of Applied Biology, Oxford, v.150, p.237-252, 2007.

COOKSON, S.J.; MORENO, M.J.C.; HEVIN, C.; Mendome, L.Z.N.; DELROT, S.; TROSSAT-MAGNIN, C.; OLLAT, N. Graft union formation in grapevine induces transcriptional changes related to cell wall modification, wounding, hormone signalling, and secondary metabolism. Journal of Experimental Botany, Oxford, v.64, n.10, p.2997-3008, 2013.

COOMBS, J.; HALL, D.O.; LONG, S.P.; SCURLOCK, J.M. Techniques in bioproductivity and photosynthesis. Oxford: Pergamon, 1987.

DAS, B.; DHAKAR, M.K. Effect of interstock on growth of vigorous mango cultivars under eastern plateau and hill region of india. Vegetos, New Delhi, v.29, p.-5, 2016.

DE MICCO, V.; ARONNE, G. Morpho-anatomical traits for plant adaptation to drought. AROCA, R. (ed.). Plant responses to drought stress. Heidelberg: Springer, 2012. p.37-61.

DI VAIO, C.; CIRILLO, C.; BUCCHERI, M.; LIMONGELLI, F. Effect of interstock (M. 9 and M. 27) on vegetative growth and yield of apple trees (cv "Annurca"). Scientia Horticulturae, New York, v.119, n.3, p. $270-274,2009$.

DUBOIS, M.; GILLES, K.A.; HAMILTON, J.K.; REBERS, P.A.; SMITH, F. Colorimetric method for determination of sugars and related substances. Journal of Analytical Chemistry, New York, v.28, p.350-356, 1956.

DUNCAN, D.B. Multiple range and multiple F tests. Biometrics, San Francisco, v.11, n.1, p.1-42, 1955.

EL-AFRY, M.M.; EL-NADY, M.F.; ABDELMONTELEB, E.B.; METWALY, M.M.S. Anatomical studies on droughtstressed wheat plants (Triticum aestivumL.) treated with some bacterial strains. Acta Biológica, Szege, v.56, n.2, p.165-174, 2012. 
EL-NABI, A.H.; KHALIL, A.E.; EL-BASET, S.A. ; MASSOUD, S. Screening of vineyards rootstock and cultivars for resistance to root-knot nematode (Meloidogyne incognita). Journal of Plant Protection and Pathology, Mansoura, v.4, n.1, p.23-34, 2013.

EL-TANANY, M.M.; SALLAM, A.A.; ABDALLAH, H.R. Irrigation scheduling, balady lime interstock and foliar potassium application in relation to Washington navel orange productivity. Middle East Journal of Agriculture Research, v.8, n.2, p.699-731, 2019.

ENNAJEH, M.; VADEL, A. M.; COCHARD, H.; KHEMIRA, H. Comparative impacts of water stress on the leaf anatomy of a drought-resistant and a drought-sensitive olive cultivar. Journal of Horticultural Science \& Biotechnology, Ashford, v.85, n.4, p.289-294, 2010.

ERTI, D.M.; AGUS, S. The potencial of interstock use to reduce diplodia disease (Botryodiplodia Theobromae Path.) on citrus plant. Russian Journal of Agricultural and Socio-Economic Sciences, Orel, v.6, n.78, p.476487, 2018.

FAO - Food and Agriculture Organization of the United Nations. Faostat. Rome, 2018. Disponível em: http:// www.fao.org/faostat/en/\#data/QC. Acesso em: 10 oct. 2020 .

FAROOQ, M.; HUSSAIN, M.; WAHID, A.; SIDDIQUE, K.H.M. Drought stress in plants: an overview. In: AROCA, R. (ed.). Plant responses to drought stress. Heidelberg: Springer, 2012. p.1-33.

FLEXAS, J.; BARON, M.; BOTA, J.; DUCRUET, J.M.; GALLE, A.; GALMES, J.; JIMENEZ, M.; POU, A.; Ribas-Carbo, M.; SAJNANI, C.; TOMAS, M.; MEDRANO, H. Photosynthesis limitations during water stress acclimation and recovery in the drought-adapted Vitis hybrid Richter-110 (V.berlandieri-V. rupestris). Journal of Experimental Botany, Oxford, v.60, n.8, p.2361-2377, 2009.

FOZOUNI, M.,; ABBASPOUR,N.; BANCH, H.D. Short term response of grapevine grown hydroponically to salinity: Mineral composition and growth parameters. Vitis, Siebeldingen, v.51, n.3, p.95-101, 2012.

GIL-IZQUIERDO, A.; RIQUELME, M.T.; PORRAS, I.; FERRERES, F. Effect of the rootstock and interstock grafted in lemon tree (Citrus limon (L.) Burm.) on the flavonoid content of lemon juice. Journal of Agricultural and Food Chemistry, Washington, v.52, n.2, p.324-331, 2004.
GIMENO, V.; SYVERTSEN, J.P.; NIEVES, M.; SIMÓN, I.; MARTÍNEZ, V.; GARCIA-SANCHEZ, F. Orange varieties as interstocks increase the salt tolerance of lemon trees. Journal of Horticultural Science \& Biotechnology, Ashford, v.84, n.6, p.625-631, 2009.

GIMENO, V.; SYVERTSEN, J.P.; SIMON, I.; MARTINEZ, V.; CAMARA-ZAPATA, J.M.; NIEVES, M.; GARCIASANCHEZ, F. Interstock of 'Valencia' orange affects the flooding tolerance in 'Verna'lemon trees. HortScience, Alexandria, v.47, n.3, p.403-409, 2012.

GIRARDI, E.A.; FILHO, F.D.A.A.M. Production of interstocked 'Pera'sweet orange nursey trees on'Volkamer 'lemon and 'Swingle'citrumelo rootstocks. Scientia Agricola, Piracicaba, v.63, n.1, p.5-10, 2006.

HAMEED, M.; BATOOL, S.; NAZ, N.; NAWAZ, T.; ASHRAF, M. Leaf structural modifications for drought tolerance in some differentially adapted ecotypes of blue panic (Panicum antidotaleRetz.). Acta Physiologiae Plantarum, Heidelberg, v.34, p.1479-1491, 2012.

HAMMERSCHMIDT, R.; NUCKLES, F.; KUC, J. Association of enhanced peroxidase activity with induced systemic resistance of cucumber to Colletotrchum lagenarium. Physiological Plant Pathology, Oxford, v.20, p.73-82, 1982.

JOGAIAH, S.; RAMTEKE, S.D.; SHARMA, J.; UPADHYAY, A.K. Moisture and salinity stress induced changes in biochemical constituents and water relations of different grape rootstock cultivars. International Journal of Agronomy, London, v.2014, n.2, p.1-8, 2014.

KAPOOR, D.; BHARDWAJ, S.; LANDI, M.; SHARMA, A.; RAMAKRISHNAN, M.; SHARMA, A. The Impact of drought in plant metabolism: how to exploit tolerance mechanisms to increase crop production. Applied Sciences, Bucharest, v.10, p.1-19, 2020.

KHAN, F.A.; BANDAY, F.A.; NARAYAN, S.; KHAN, F.U.; BHAT, S.A. Use of models as non-destructive method for leaf area estimation in horticultural crops. International Journal of Molecular Sciences, Basel, v.4, n.1, p.162-180, 2016.

KOUNDOURAS, S.; TSIALTAS, L.T.; ZIOZIOU, E.; NIKOLAOU, N. Rootstock effects on the adaptive strategies of grapevine (Vitis vinifera L. cv. CabernetSauvignon) under contrasting water status: Leaf physiological and structural responses. Agriculture, Ecosystems \& Environment, v.128, p.86-96, 2008. 
LEBON, E.; PELLEGRINO, A.; LOUARN, G.; LECOEUR, J. Branch development controls leaf area dynamics in grapevine (Vitis vinifera) growing in drying soil. Annals of Botany, Amsterdam, v.98, n.1, p.175-185, 2006.

LI, X.L.; ZHANG, J.K.; LI, M.J.; Zhou, B.B.; ZHANG, Q.; WEI, Q.P. Influence of six dwarfing interstocks on the 'Fuji' apple under drought stress. Indian Journal of Horticulture, New Delhi, v.74, n.3, p.346-350, 2017.

LOCATELLI, G.; PIO, R.; BISI, R.B.; DE SOUZA, F.B.M.; VIANA, M.T.R.; DA HORA FARIAS, D.; ZAMBON, C.R. Leaf anatomy of apple trees during seasonal periods under subtropical conditions. HortScience, Alexandria, v.54, n.11, p.1887-1895, 2019.

MAFAKHERI, A.; S IOSEMARDEH, A.; BAHRAMNEJAD, B.; STRUIK, P.C.; SOHRABI, Y. Effect of drought stress on yield, proline and chlorophyll contents in three chickpea cultivars. Australian Journal of Crop Science, Queensland, v.4, n.8, p.580-585, 2010.

MEDEIROS, D.B.; DA SILVA, E.C.; SANTOS, H.R.B.; PACHECO, C.M.; MUSSER, R.D.S.; NOGUEIRA, R.J.M.C. Physiological and biochemical responses to drought stress in Barbados cherry. Brazilian Journal of Plant Physiology, Campinas, v.24, n.3, p.181-192, 2012.

MEGGIO, F.; PRINSI, B.; NEGRI, A.S.; DI LORENZO, G.S.; LUCCHINI, G.; PITACCO, A.; FAILLA, O.; SCIENZA, A.; COCUCCI, M.; ESPEN, L. Biochemical and physiological responses of two grapevine rootstock genotypes to drought and salt treatments. Australian Journal of Grape and Wine Research, Glen Osmond, v.20, n.2, p.1-14, 2014.

MNG'OMBA, S.A.; DU TOIT, E.S.; AKINNIFESI, F.K. The Relationship between graft incompatibility and phenols in Uapaca kirkiana Müell Arg. Scientia Horticulturae, New York, v.117, n.3, p.212-218, 2008.

MOHAMMADKHANI, N.; HEIDARI, R. Droughtinduced accumulation of soluble sugars and proline in two maize varieties. World Applied Sciences Journal, Faisalabad, v.3, n.3, p.448-453, 2008.

MOHSEN, A.T.; STINO, R.G.; ABD ALLATIF, A.M.; ZAID, N.M. In vitro evaluation of some grapevine rootstocks grown under drought stress. Plant Archives, Muzaffarnagar, v.20, p.1029-1034, 2020.

NASSAR, M.A.; El-SAHHAR, K.F. Botanical preparations and microscopy (Microtechnique). Dokki: Academic Bookshop, 1998. p.219.
NAWAZISH, S.; HAMEED, M.; NAURIN, S. (2006). Leaf anatomical adaptations of cenchrus ciliarisl. from the salt range. pakistan against drought stress. Pakistan Journal of Botany, Karachi, v.38, n.5, p.1723-1730, 1998.

NI, X.; QUISENBERRY, S.S.; HENG-MOSS, T.; MARKWELL, J.; SARATH, G.; KLUCAS, R.; BAXENDALE, F. Oxidative responses of resistant and susceptible cereal leaves to symptomatic and non symptomatic cereal aphid (Hemiptera:Aphididae) feeding. Journal of Economic Entomology, Lanham, v.94, p.743$751,2001$.

PATAKAS, A.; STAVRAKAS, D.;FISARAKIS, I. Relationship between $\mathrm{CO} 2$ assimilation and leaf anatomical characteristics of two grapevine cultivars. Agronomie, Ottawa, v.23, n.4, p.293-296, 2003.

PECCOUX, A.; LOVEYS, B.; ZHU, J.; GAMBETTA, G.A.; DELROT, S.; VIVIN, P.; DAI, Z. Dissecting the rootstock control of scion transpiration using modelassisted analyses in grapevine. Tree Physiology, Victoria, v.38, n.7, p.1026-1040, 2017.

QUEIROZ-VOLTAN, R.B.; NARDIN, C.F.; FAZUOLI, L.C.; BRAGHINI, M.T. Leaf anatomy characterization of Coffea arabica plants at different seasonal periods. Biotemas, Florianópolis, v.27, n.1-10, 2014.

REZAEE, T.; GHOLAMI, M.; ERSHADI, A.; MOSADDEGHI, M. The effect of water deficit stress on some growth and physiological characteristics of five grapevine cultivars (vitis vinifera 1.). Agricultural Research, Greenbelt, v.7, n.4, p.199-210, 2008.

SAMI, F.; YUSUF, M.; FAIZAN, M.; FARAZ, A.; HAYAT, S. Role of sugars under abiotic stress. Plant Physiology and Biochemistry, Paris, v.109, n.54-61, 2016.

SANDERS, G.J.; ARNDT, S.K. Osmotic adjustment under drought conditions. AROCA, R. (ed.). Plant responses to drought stress. Heidelberg: Springer, 2012. p.199229.

SATISHA, J.; PRAKASH, G.S.; MURTI, G.S.R.; UPRETI, K.K. Water Stress and rootstocks influences on hormonal status of budded grapevine. European Journal of Horticultural Science, Sttugart, v.72, n.5, p. 202-205, 2007.

SATISHA, J.; RAMTEKE, S.D.; KARIBASAPP, G.S. Physiological and biochemical characterisation of grape rootstocks. South African Journal for Enology and Viticulture, Stellenbosch, v.28, n.2, p.163-168, 2007. 
SERRA, I.; STREVER, A.; MYBURGH, P. A.; DELOIRE, A. Review: the interaction between rootstocks and cultivars (Vitis vinifera L.) to enhance drought tolerance in grapevine. Australian Journal of Grape and Wine Research, Glen Osmond, v.20, p.1-14, 2014.

SHALTIEL-HARPAZ, L.; GERCHMAN, Y.; IBDAH, M.; KEDOSHIM, R.; RACHMANY, D.; HATIB, K.; HOLLAND, D. Grafting on resistant interstocks reduces scion susceptibility to pear psylla, Cacopsylla bidens. Pest Management Science, New York, v.74, n.3, p.617-626, 2018.

SHARMA, A.; SHAHZAD, B.; REHMAN, A.; BHARDWAJ, R.; LANDI, M.; ZHENG, B. Response of phenylpropanoid pathway and the role of polyphenols in plants under abiotic stress. Molecules, Basel, v.24, n.13, p.1-22, 2019.

SILVA, S. da; DE CASTRO, E.M.; SOARES,A.M. Effects of different water regimes on the anatomical characteristics of roots of grasses promising for revegetation of areas surrounding hydroelectric reservoirs. Ciência e Agrotecnologia, Lavras, v.27, n.2, p.393-397, 2003.

SOAR, C.J.; DRY, P.R.; LOVEYS, B.R. Scion photosynthesis and leaf gas exchange in Vitis vinifera $\mathrm{L}$. cv. Shiraz: mediation of rootstock effects via xylem sap ABA. Australian Journal of Grape and Wine Research, Glen Osmond, v.12, p.82-96, 2006

SOSNA, I.; KORTYLEWSKA, D. Estimation of interstock and intermediate stock usefulness for summer pear cvs. budded on two rootstocks. Journal of Horticultural Research, Skierniewice, v.21, n.1, p.79-82, 2013.

SUCU, S.; YAĞCI, A.; YILDIRIM, K. Changes in morphological, physiological traits and enzyme activity of grafted and ungrafted grapevine rootstocks under drought stress. Erwerbs-Obstbau, Berlin, v.60, n.2, p.127-136, 2018

SURENDAR, K.K.; DEVI, D.D.; RAVI, I.; JEYAKUMAR, P.; VELAYUDHAM, K. Effect of water stress on leaf temperature, transpiration rate, stomatal diffusive resistance and yield of banana. Plant Gene and Trait, Richmond, v.4, n.8, p.43-47, 2013.

TARATIMA, W.; RITMAHA, T.; JONGRUNGKLANG, N.; MANEERATTANARUNGROJ, P.; KUNPRATUM, N. Effect of stress on the leaf anatomy of sugarcane cultivars with different drought tolerance (Saccharum officinarum, Poaceae). Revista de Biología Tropical, San José, v.68, n.4, p.1159-1170, 2020.
TARATIMA, W.; RITMAHA, T.; JONGRUNGKLANG, N.; RASO, S.; MANEERATTANARUNGROJ, P. Leaf anatomical responses to drought stress condition in hybrid sugarcane leaf (Saccharum officinarum 'KK3'). Malaysian Applied Biology Journal, Kuala Lumpur, v.48, p.180-188, 2019.

TOSCANO, T.; FERRANTE, A.; ROMANO, D. Response of mediterranean ornamental plants to drought stress. Horticulturae, Basel, v.5, n.6, p.1-20, 2019.

TOUMI, I.; M'SEHLI, W.; BOURGOU, S.; JALLOULI, N.; BENSALEM-FNAYOU, A.; GHORBEL, A.; MLIKI, A. Response of ungrafted and grafted grapevine cultivars and rootstocks (Vitis sp.) to water stress. Journal International des Sciences de la Vigne et du Vin, Villenave d'Ornon, v.41, n.2, p.85-93, 2007.

TRAMONTINI, S.; VITALI, M.; CENTIONI, L.; SCHUBERT, A.; LOVISOLO, C. Rootstock control of scion response to water stress in grapevine. Environmental and Experimental Botany, Amsterdam, v.93, p.20-26, 2013.

TSEGAY, D.; AMSALEM, D.; ALMEIDA, M.; CRANDLES, M. Responses of grapevine rootstocks to drought stress. International Journal of Plant Physiology and Biochemistry, Paris, v.6, n.1, p.1-6, 2014

VERMA, S. K.; SINGH, S. K.; KRISHNA, H. The effect of certain rootstocks on the grape cultivar 'Pusa Urvashi'(Vitis vinifera L.). International Journal of Fruit Science, Binghamton, v.10, p.16-28, 2010.

WILLIAMS, L.E. Interaction of rootstock and applied water amounts at various fractions of estimated evapotranspiration (ETc) on productivity of Cabernet Sauvignon. Australian Journal of Grape and Wine Research, Glen Osmond, v.16, p.434-444, 2010.

ZAPATA, J.C.; NIEVES, M.; CERDÁ, A. Improvement in growth and salt resistance of lemon (Citrus limon) trees by an interstock-induced mechanism. Tree Physiology, Victoria, v.23, p.879-888, 2003.

ZULFIQAR, F.; YOUNIS, A.; RIAZ, A.; MANSOOR, F.; HAMEED, M.; AKRAM, N.A.; ABIDEEN, Z. Morphoanatomical adaptations of two tagetes erecta 1 . cultivars with contrasting response to drought stress. Pakistan Journal of Botany, Karachi, v.52, n.3, 801-810, 2020. 